\title{
SOCIAL AND LABOUR PRACTICES OF CORPORATES IN FOOD INDUSTRY
}

\author{
T. Berezianko \\ National University of Food Technologies
}

\begin{tabular}{|c|c|}
\hline Key words: & ABSTRACT \\
\hline $\begin{array}{l}\text { Social responsibility } \\
\text { Labour practices } \\
\text { Survey } \\
\text { EU } \\
\text { Evaluation } \\
\text { Remuneration strategy } \\
\end{array}$ & $\begin{array}{l}\text { Corporate social responsibility is recognized as a tool for } \\
\text { implementation of the conflict free system of market } \\
\text { development. Hence, it put a key focus on the analysis of } \\
\text { social and labour practices of the entities operating in food } \\
\text { industry. As a part of this research we used EU methodology } \\
\text { adapted for national environment. Some gaps were filled by }\end{array}$ \\
\hline $\begin{array}{l}\quad \text { Article history: } \\
\text { Received 05.11.2017 } \\
\text { Received in revised form } \\
29.11 .2017 \\
\text { Accepted } 08.12 .2017 \\
\end{array}$ & $\begin{array}{l}\text { the conclusions received in a course of private interviews. } \\
\text { The implementation of European market society standards } \\
\text { urges the companies to put in place the responsibility- } \\
\text { centered labour relationships as a daily practice. To analyze } \\
\text { the labour practice of the corporates we investigated the }\end{array}$ \\
\hline $\begin{array}{l}\text { Corresponding author: } \\
\text { T. Berezianko } \\
\text { E-mail: } \\
\text { npnuht@ukr.net }\end{array}$ & $\begin{array}{l}\text { remuneration strategy, regularity of salary changes, systems } \\
\text { of variable bonuses, remuneration gaps for certain positions. } \\
\text { We paid separate attention to the attitude of the managers } \\
\text { towards their employees as company's competitive advan- } \\
\text { tage. As a result of our research we identified the perso- } \\
\text { nnel's attitude towards the company and defined the level of } \\
\text { conflict prone situations between employees, managers and } \\
\text { the owners. As a final point of our research, we evaluated } \\
\text { the level of corporate social responsibility due to the EU } \\
\text { methodology. }\end{array}$ \\
\hline
\end{tabular}

DOI: $10.24263 / 2225-2924-2017-23-6-9$

\section{СОЦІАЛЬНО-ТРУДОВІ ПРАКТИКИ ПІДПРИЕМСТВ ХАРЧОВОЇ ПРОМИСЛОВОСТІ}

\section{Т.В. Березянко \\ Національний університет харчових технологій}

Інструментом створення безконфліктної системи розвитку в ринкових умовах визнано впровадження системи суспільної та соиіальної відповідальності бізнесу, тому аналіз соиіально-трудових практик підприємств харчовоі промисловості став головним акиентом даного дослідження. Використовувалась адаптована до національних умов методика СС, деякі прогалини доповнювались відповідями індивідуальних інтерв 'ю. Стандарти відповідальних трудових відносин європейського ринкового суспільства потребують впровадження у щоденну практику діяльності компанії. 3 метою аналізу трудової практики підприємств досліджено стратегію оплати, періодич- 
ність зміни ставки, стратегію винагороди, змінні бонуси, розбіжності оплати окремих посад. Також увагу приділено ставленню керівників до персоналу, як до конкурентної переваги. В результаті дослідження виявлено ставлення прачівників до компанії та визначено рівень конфліктності між прачівниками, менеджментом і власниками. Дослідження завершене оцінкою рівня корпоративної соиіальної відповідальності, виконаного за методикою ЄС.

Ключові слова: сочіальна відповідальність, трудові практики, анкетування, $€ C$, очінка, стратегія винагороди.

Постановка проблеми. Харчова промисловість відіграє особливу роль у вирішенні продовольчого забезпечення будь-якої країни. Експертами визнається, що харчова промисловість є тим двигуном, що може не тільки забезпечити суттєве зростання ВВП, а й пом'якшити тиск кризових явищ у національній економіці.

У ЄС дотримання вимог корпоративної соціальної відповідальності (КСВ) вважається основним чинником залучення інвестицій від інституціональних організацій. За результатом дослідження Світової ради бізнесу із стабільного розвитку, орієнтація на соціальну відповідальність і державне партнерство надають додаткові можливості в обсязі 6,2 млрд дол. США для компаній, що їх застосовують[1]. Реалізація Концепції соціальної відповідальності передбачає впровадження у щоденну практику діяльності компанії комплексу аспектів організації відповідального управління, дотримання прав людини у процесі діяльності, налагодження соціально відповідальних трудових відносин, ведення чесної операційної діяльності, захист навколишнього середовища, дотримання та розвиток системи захисту прав споживача, підтримку розвитку місцевих громад і співпраця з ними.

Міжнародна конференція МОП виокремила шість основних принципів, які допомагають підприємству зберігати стійкість і темпи розвитку [2]. Першим i основним $є$ встановлення соціального діалогу та нормалізація умов праці (не тільки у плані безпеки та фізіологічних вимог), а й проведення колективних переговорів і консультацій, залучення працівників до участі у виробничому процесі на основі безконфліктних стосунків.

У сучасних умовах рафінованої конкуренції кваліфікований персонал $є$ не тільки основою досягнення конкурентних переваг, а й гарантією збереження та розвитку потенціалу відповідального підприємства.

Аналіз останніх досліджень і публікацій. Науковці всього світу наголошують на необхідності використання гідної оцінки праці як головної умови забезпечення стабільності в бізнесі та країні. Сучасним аспектам цього напрямку присвячено праці багатьох зарубіжних і вітчизняних дослідників [3-8].

Мета статті: дослідження трудових практик, визначення рівня відповідності або наближення до вимог організації відповідального управління, дотримання прав людини у процесі діяльності, налагодження соціально відповідальних трудових відносин у контексті реалізації завдань Концепції соціальної відповідальності ЄС. 
Матеріали і методи. Основним матеріалом виконання дослідження слугували анкетні дані, експертні опитування та згруповані матеріали індивідуальних інтерв'ю. В результаті статистичного аналізу отриманих даних анкетних відповідей було побудовано матрицю спряженості, для якої розраховано коефіцієнт Пірсона.

Результати і обговорення. Проведене протягом 2009-2016 рр. опитування у 34 компаніях харчової промисловості, а також експертів-практиків дало змогу сформувати нижченаведий масив інформації. Суспільно відповідальні підприємства повинні використовувати корпоративну соціальну відповідальність, аби досягти стійких результатів. Цей підхід закріплено у Тристоронній декларації МОП щодо корпорацій і соціальної політики.

Таблиия 1. Отримані ефекти від впровадження елементів соціально відповідальної поведінки

\begin{tabular}{|c|c|c|c|c|}
\hline Показник & $\begin{array}{c}\text { Харчова } \\
\text { промисловість }\end{array}$ & $\begin{array}{c}\text { Олігопольне } \\
\text { ядро }\end{array}$ & $\begin{array}{c}\text { Великі } \\
\text { підприємства }\end{array}$ & $\begin{array}{c}\text { Середні } \\
\text { підприємства }\end{array}$ \\
\hline Плинність кадрів, \% & $16-60$ & $9,5-16,9$ & 16,6 & 21,5 \\
\hline $\begin{array}{c}\text { Продуктивність } \\
\text { праці, тис. грн/осіб }\end{array}$ & - & 12,7 & 7,1 & 14,8 \\
\hline $\begin{array}{c}\text { Рівень контрактної } \\
\text { культури }\end{array}$ & - & - & + & + \\
\hline $\begin{array}{c}\text { Понаднормове } \\
\text { навантаження, \% }\end{array}$ & 73,0 & 90,3 & 89,9 & 12 \\
\hline $\begin{array}{c}\text { Неповна } \\
\text { зайнятість, \% }\end{array}$ & 30 & 22 & 11 & 21 \\
\hline $\begin{array}{c}\text { Кількість заяв на } \\
\text { одну вакансію }\end{array}$ & $3-4$ & 6 & 43 & + \\
\hline $\begin{array}{c}\text { Задоволеність } \\
\text { працею, \% }\end{array}$ & 34 & 37 & + & + \\
\hline Гендерна рівність & - & - & + & + \\
\hline $\begin{array}{c}\text { Умови та безпека } \\
\text { праці }\end{array}$ & + & - & + & + \\
\hline $\begin{array}{c}\text { Працевлаштування } \\
\text { людей з обмеженими } \\
\text { можливостями }\end{array}$ & - & - & & + \\
\hline
\end{tabular}

Стратегія винагороди працівників залежить від розміру та приналежності компанії. Нами проаналізовані окремі посади на обраних підприємствах. Для забезпечення правила роботи 3 мінімальною вибіркою було розглянуто такі позиції:

- стратегія винагороди, позиція компанії у сфері оплати праці в ринковому сегменті та регіоні, періодичність перегляду ставки оплати праці, наявність категорії «ключовий співробітник»;

- оцінка ефективності праці співробітників, наявність методики оцінки, періодичність оцінки, вплив оцінки на результати винагороди;

- змінні бонуси.

Так, зафіксовано зниження рівня задоволення працею у харчовій промисловості, підвищення плинності кадрів, зростання рівня навантаження, а також інші негативні зміни в кадровій політиці. Працівники пов'язують це 3 необхідністю економії у час кризи і скороченням соціальних виплат на під- 
приємствах - захід економіі. Принаймні таке відмітили 67\% співробітників підприємств, що брали участь в опитуванні [9; 10].

Таблиця 2. Стратегія винагороди працівників, \%, укладено автором

\begin{tabular}{|c|c|c|c|c|c|}
\hline Показник & Олігопольне ядро & $\begin{array}{c}\text { Великі } \\
\text { підпр. }\end{array}$ & $\begin{array}{c}\text { Середні } \\
\text { підпр. }\end{array}$ & $\begin{array}{c}\text { Малі } \\
\text { підпр. }\end{array}$ & $\begin{array}{c}\text { Мікро- } \\
\text { підпр. }\end{array}$ \\
\hline $\begin{array}{c}\text { Вчасність виплати } \\
\text { зарплати }\end{array}$ & 100 & 92 & 78 & 50 & 50 \\
\hline $\begin{array}{c}\text { Щорічний перегляд } \\
\text { зарплат }\end{array}$ & 75 & 40 & 15 & - & - \\
\hline Відповідність ринку & 90 & 65 & 40 & 20 & - \\
\hline $\begin{array}{c}\text { Виокремлення } \\
\text { «ключового персоналу» }\end{array}$ & 15 & - & - & - & - \\
\hline $\begin{array}{c}\text { Наявність системи } \\
\text { оцінки ефективності } \\
\text { персоналу }\end{array}$ & 40 & 35 & 15 & - & - \\
\hline $\begin{array}{c}\text { Наявність змінної } \\
\text { частини винагороди }\end{array}$ & 60 & 50 & 50 & 25 & 15 \\
\hline Рівень навантаження & 1,8 & 1,6 & 1,2 & 1 & 1 \\
\hline
\end{tabular}

У більшості випадків стратегія оплати орієнтовна на середнє значення по ринку для середніх і малих підприємств, знаходиться на рівні верхнього значення або незначним чином перевищує його - для великого бізнесу підгалузі і значно випереджає — для підприємств олігопольного ядра із значною іноземною часткою.

Таблиия 3. Прозорість стратегії додаткової винагороди, \%

\begin{tabular}{|c|c|c|c|c|c|}
\hline Показник & $\begin{array}{c}\text { Олігопольне } \\
\text { ядро }\end{array}$ & $\begin{array}{c}\text { Великі } \\
\text { підпр. }\end{array}$ & $\begin{array}{c}\text { Середні } \\
\text { підпр. }\end{array}$ & $\begin{array}{c}\text { Малі } \\
\text { підпр. }\end{array}$ & $\begin{array}{c}\text { Мікро- } \\
\text { підпр. }\end{array}$ \\
\hline $\begin{array}{c}\text { Виплати за продуктивність } \\
\text { праці }\end{array}$ & 11,2 & 5,1 & 1,2 & - & - \\
\hline Гарантовані виплати* & 86,3 & 90,1 & 84,2 & - & - \\
\hline $\begin{array}{c}\text { Компенсації за ненормований } \\
\text { робочий графік }\end{array}$ & 2,3 & - & - & - & - \\
\hline Грошові пільги & 28,1 & 12,2 & 2,0 & - & - \\
\hline Матеріальні пільги & 17,4 & 5,3 & 4,7 & - & - \\
\hline
\end{tabular}

До складу гарантованих виплат включено заробітну плату за штатним розкладом і фіксовані бонуси: доплати за стаж, кваліфікацію та професійні навички, що не прив'язані до бізнес-діяльності компанії, які можуть виплачуватись у кінці року або щомісячно.

Жодна із досліджених компаній не дотримується на практиці 40-годинного робочого тижня, але і не нараховує додаткової платні за понаднормові витрати робочого часу. Лише у двох компаніях у фабулі контракту зазначений рядок щодо компенсації понаднормових витрат робочого часу при розрахунку оплати відпустки. Практично у всіх компаній ведеться контроль щорічних відпусток, 6\% компаній надають своїм працівникам додаткові дні до відпустки. Ця практика застосовується здебільшого у середніх компаніях, що були раніше самостійними заводами з переробки харчової продукції. При 
цьому враховується стаж роботи на підприємстві, а не індивідуальні понаднормові витрати часу. На 64\% малих і мікропідприємствах протягом року застосовувалась практика надання короткострокових відпусток без надання лікарняного листа. Ця пільга використовувалась усіма категоріями співробітників. Середня тривалість вказаного періоду становила 4 дні, але застосовувалась 2-3 рази на рік, що сумарно складає 12 днів повної оплати неформалізованої відпустки.

Половина компаній, здебільшого великого та середнього корпоративного сегменту, надавала співробітникам додаткові оплачувані відпустки 3 поважних причин. Найбільш вживаною аргументацією були: весілля - 32\%; догляд за дитиною або близькими - 30\%; нетерміновий ремонт сантехніки та автомобіля - 18\%; відвідування лікаря — 10\%; похорон - 4\%; народження дитини - 3\%.

Лише 13\% компаній проводять формалізовану оцінку ефективності діяльності персоналу, яка базується на досягненні поставлених цілей і критеріях оцінки праці.

Таблиця 4. Вплив факторів визначення внеску до сукупного прибутку на винагороду персоналу, \%, укладено за матеріалами MAZARS та інтерв’ю

\begin{tabular}{|c|c|c|c|}
\hline Показник & $\begin{array}{c}\text { Результати діяльності } \\
\text { підприємства }\end{array}$ & $\begin{array}{c}\text { Результати } \\
\text { діяльності } \\
\text { команди }\end{array}$ & $\begin{array}{c}\text { Індивідуальні } \\
\text { результати }\end{array}$ \\
\hline Топ-менеджмент & - & - & - \\
\hline $\begin{array}{c}\text { Менеджмент середньої } \\
\text { ланки }\end{array}$ & 85 & 10 & 14 \\
\hline $\begin{array}{c}\text { Спеціалісти бізнес- } \\
\text { функцій }\end{array}$ & 60 & 26 & 16 \\
\hline $\begin{array}{c}\text { Спеціалісти } \\
\text { адмінфункцій }\end{array}$ & 60 & - & 20 \\
\hline Спеціалісти з продажу & 80 & 30 & 15 \\
\hline Робочий персонал & 55 & - & - \\
\hline Ключовий персонал & - & & \\
\hline
\end{tabular}

Доволі значний інтерес представляє фактор «бонуси та пільги», який іноді стає засобом неформальної заробітної плати. 3 боку компанії надання пільг і бонусів є вагомим засобом винагороди персоналу та суттєвою статтею витрат компаніі. Фактичні бонуси нараховуються співробітникам за досягнення бізнес-цілей (індивідуальних, групових, корпоративних) і виплачуються у кінці року, півріччя або кварталу чи бізнес-сезону. До їх складу включаються доплати за особливі умови праці, комісійні від продажу.

Таблиця 5. Ставлення керівників харчової промисловості до персоналу як конкурентної переваги, \%, укладено автором за джерелом: [11]

\begin{tabular}{|c|c|c|c|c|c|c|}
\hline Показник & $\begin{array}{c}\text { Київська } \\
\text { обл. }\end{array}$ & $\begin{array}{c}\text { Харківська } \\
\text { обл. }\end{array}$ & $\begin{array}{c}\text { Полтавська } \\
\text { обл. }\end{array}$ & $\begin{array}{c}\text { Хмельницька } \\
\text { обл. }\end{array}$ & $\begin{array}{c}\text { Вінницька } \\
\text { обл. }\end{array}$ & $\begin{array}{c}\text { АР } \\
\text { Крим }\end{array}$ \\
\hline 1 & 2 & 3 & 4 & 5 & 6 & 7 \\
\hline $\begin{array}{c}\text { Наявність } \\
\text { кваліфікованих } \\
\text { працівників }\end{array}$ & 70 & 40 & 57 & 32 & 69 & 30 \\
\hline
\end{tabular}




\begin{tabular}{|c|c|c|c|c|c|c|}
\hline \multicolumn{1}{|c|}{\begin{tabular}{c}
\multicolumn{5}{c}{ Пршовово робочан } \\
сила
\end{tabular}} & 31,1 & 50 & 20 & 30 & 44 & 60 \\
\hline $\begin{array}{c}\text { Політика } \\
\text { жорсткого } \\
\text { середовища }\end{array}$ & 60 & 67 & 43 & 55 & 82 & 44 \\
\hline $\begin{array}{c}\text { Стимулювання } \\
\text { ротації кадрів }\end{array}$ & 44 & 54 & 58 & 62 & 70 & 44 \\
\hline $\begin{array}{c}\text { Частка } \\
\text { підприємств } \\
\text { харчової } \\
\text { продукції }\end{array}$ & 36,4 & 25,4 & 17,4 & 29,4 & 54,6 & 28,3 \\
\hline
\end{tabular}

Часто змінні бонуси виплачуються за результатами роботи або оцінки $\mathrm{i}$ розраховуються як відсоток від заробітної плати. Крім того, використовуються цільові бонуси у вигляді відсотка до зарплати, які нараховуються за досягнення працівником 100\% поставлених цілей. До складу показника загальна винагорода включено всі види доплат, бонусів і наданих пільг у перерахунку на грошовий еквівалент за цінами ринку.

Таблиия 6. Структура пільг на підприємствах корпоративного сектору харчової промисловості, \%

\begin{tabular}{|c|c|c|c|c|}
\hline Показники & $\begin{array}{c}\text { Корпоративне } \\
\text { ядро }\end{array}$ & $\begin{array}{c}\text { Великі } \\
\text { підприємства }\end{array}$ & $\begin{array}{c}\text { Середні } \\
\text { підприємства }\end{array}$ & $\begin{array}{c}\text { Малі } \\
\text { підприємства }\end{array}$ \\
\hline $\begin{array}{c}\text { Харчування, } \\
\text { проживання, } \\
\text { проїзд }\end{array}$ & 37,1 & 63,1 & $28,8^{*}$ & 11,2 \\
\hline $\begin{array}{c}\text { Медичне } \\
\text { страхування }\end{array}$ & 89,6 & 32,1 & - & - \\
\hline $\begin{array}{c}\text { Корпоративні, } \\
\text { спортивні та } \\
\text { соціальні заходи }\end{array}$ & 76,2 & 18,4 & - & 23,4 \\
\hline $\begin{array}{c}\text { Оплата } \\
\text { мобільного } \\
\text { зв’язку }\end{array}$ & 96,1 & 28,6 & 21,2 & - \\
\hline $\begin{array}{c}\text { Корпоративні } \\
\text { автомобілі }\end{array}$ & 31,4 & 10,3 & - & - \\
\hline $\begin{array}{c}\text { Фінансові пільги, } \\
\text { позики, допомога }\end{array}$ & 35,2 & 7,2 & - & - \\
\hline
\end{tabular}

Примітка* У групі опитаних підприємств зафіксовано лише компенсацію проїзду, але за даними інтерв'ю наявна оплата харчування.

Мейнстримом сучасного періоду є проголошення корпоративної соціальної відповідальності ключовим показником ефективності (KPIs), що використовуються для оцінки діяльності як співробітників, так і самої компанії. Показники КСВ включено в оцінку топ-менеджменту та менеджерів середньої ланки при виплаті бонусів: досягнення показників КСВ дає змогу отримувати $10 \%$ бонусів у компанії ALPRO Soya (виробник соєвих напоїв, CША) [12 ]; 20\% - y SONY; 33\% — y Danone [ 13] ; 40\% — y Enel [14 ]. B CC KCB KPIs включено в оцінку роботи керівників усіх рівнів і співробітників. Це дає змогу перейти від декларації намірів і прагнень до реального втілення вимог. 
Таблиия 7. Виплата бонусів за групами ікатегоріями персоналу досліджуваних компаній харчової промисловості, укладено автором за результатами опитування та інтерв'ю

\begin{tabular}{|c|c|c|c|c|c|}
\hline Показник & $\begin{array}{c}\text { Виплати за } \\
\text { прдуктивність } \\
\text { праці }\end{array}$ & $\begin{array}{c}\text { Гарантовані } \\
\text { виплати }\end{array}$ & $\begin{array}{c}\text { Компенсації за } \\
\text { не нормований } \\
\text { робочий графік }\end{array}$ & $\begin{array}{c}\text { Грошові } \\
\text { пільги }\end{array}$ & $\begin{array}{c}\text { Матеріальні } \\
\text { пільги }\end{array}$ \\
\hline Топ-менеджмент & & $*$ & & $*$ & $*$ \\
\hline $\begin{array}{c}\text { Менеджмент } \\
\text { середньої ланки }\end{array}$ & & $*$ & & $*$ & $*$ \\
\hline $\begin{array}{c}\text { Спеціалісти } \\
\text { бізнес-функцій }\end{array}$ & $*$ & $*$ & & & $*$ \\
\hline $\begin{array}{c}\text { Спеціалісти } \\
\text { адміністратив } \\
\text { них функцій }\end{array}$ & & $*$ & & $*$ & \\
\hline $\begin{array}{c}\text { Спеціалісти 3 } \\
\text { продажу }\end{array}$ & $*$ & $*$ & & & \\
\hline $\begin{array}{c}\text { Виробничий } \\
\text { персонал }\end{array}$ & $*$ & $*$ & & & $*$ \\
\hline
\end{tabular}

Характерним для всіх підприємств $є$ відсутність виокремлення групи ключового персоналу у складі працівників.

Таблиця 8. Оцінка компанії працівниками (бали, 5 - максимально), укладено автором за результатами опитування та інтерв’ю

\begin{tabular}{|c|c|c|c|c|c|}
\hline Показники & Олігопольне ядро & Великі & Іноземні & Середні & Малі \\
\hline $\begin{array}{c}\text { Колектив і } \\
\text { корпоративна культура }\end{array}$ & 3 & 2 & 4 & 3 & 1 \\
\hline $\begin{array}{c}\text { Керівництво та } \\
\text { ставлення до } \\
\text { працівників }\end{array}$ & 2 & 1 & 5 & 2 & 3 \\
\hline Умови роботи & 4 & 5 & 5 & 3 & 2 \\
\hline $\begin{array}{c}\text { Соціальний пакет і } \\
\text { пільги }\end{array}$ & 3 & 3 & 5 & 1 & 1 \\
\hline $\begin{array}{c}\text { Перспективи } \\
\text { професійного росту }\end{array}$ & 2 & 1 & 2 & 1 & 1 \\
\hline
\end{tabular}

3 точки зору розподілу фонду оплати праці очевидною є практика відсутності компенсації понаднормового використання робочого часу, гарантовані виплати є квартальною премією і вважаються додатком до ставки заробітної плати, у категорії «робочий персонал» гарантовані виплати та премія за продуктивність праці збігаються і часто заміщують одне одного.

Другу проблему складає зростання тенденцій конфліктності, маніпуляцій i свідомої стагнації у менеджменті крупних та олігопольних структур.

Протягом досить довгого часу в наукових публікаціях відбувалась полеміка щодо ринкової доцільності формування в компанії культури організації як складової ефективного менеджменту.

Типовими причинами, які не дають змоги реалізувати потенціал об'єднання зарубіжних компаній, $є$ розбіжність у підходах до управління; несхожість корпоративних культур; відсутність планів для до- i після інтеграційного 
періодів; недостатня увага до поточного бізнесу або критично важливих завдань інтеграції; низький рівень управління ризиками; нереалістична оцінка затрат, строків і перешкод; неефективне управління програмою інтеграції після укладення угоди.

Таблиия 9. Рівень конфліктності відносин між робітниками та менеджментом/ власником (кількість обстежених підприємств), укладено автором за результатами опитування та інтерв'ю

\begin{tabular}{|c|c|c|c|c|}
\hline \multirow{2}{*}{ Підприємства } & \multicolumn{4}{|c|}{ Рівень конфліктності на підприємстві } \\
\cline { 2 - 5 } & незначний & середній & високий & $\begin{array}{c}\text { мотивація до } \\
\text { звільнення }\end{array}$ \\
\hline Малі & 6 & 1 & 1 & - \\
\hline Середні & 1 & 9 & 1 & - \\
\hline Великі & 1 & 2 & 2 & 2 \\
\hline Олігопольні & - & - & 1 & 2 \\
\hline
\end{tabular}

Отримані результати надають можливість перейти до узагальненої оцінки трудових практик підприємств харчової промисловості на основі методик КСB EC.

Таблиця 10. Рівень соціальної та суспільної відповідальності в корпоративному секторі харчової промисловості, укладено автором

\begin{tabular}{|c|c|c|c|c|}
\hline Напрямок КСВ & Олігопольні & Великі & Середні & Малі \\
\hline Формалізація політики КСВ & $*$ & & & \\
\hline $\begin{array}{c}\text { Розкриття інформації про } \\
\text { компанію }\end{array}$ & $*$ & & & \\
\hline Наявність соціальних програм & $*$ & $*$ & $*$ & \\
\hline Наявність перенавчання & $*$ & $*$ & $*$ & $*$ \\
\hline $\begin{array}{c}\text { Формалізація етики ставлення } \\
\text { до споживача }\end{array}$ & $*$ & $*$ & $*$ & \\
\hline $\begin{array}{c}\text { Співпраця з громадою } \\
\text { (програми) }\end{array}$ & $*$ & $*$ & & \\
\hline Етика відносин із акціонерами & $*$ & $*$ & & \\
\hline Екологічні програми & $*$ & & & \\
\hline
\end{tabular}

Отримані результати підтвердили висновок, що переважно компанії, які проходять лістинг, особливо на іноземних фондових біржах, і мають ділові стосунки 3 компаніями 3 Європи впроваджують принципи соціальної відповідальності бізнесу. Проте в процесі було виявлено тенденцію, що у значній кількості випадків цей процес навіть серед компаній олігопольного ядра має здебільшого формальний характер.

Таблиця 11. Оцінка рівня розвитку принципів корпоративної соціальної відповідальності в політиках компаній харчової промисловості, укладено автором за даними звітності SMIDA

\begin{tabular}{|c|c|c|c|c|}
\hline $\begin{array}{c}\text { Напрямок КСВ } \\
\text { політики }\end{array}$ & $\begin{array}{c}\text { Максимальна } \\
\text { оцінка }\end{array}$ & $\begin{array}{c}\text { Олігопольне } \\
\text { ядро }\end{array}$ & $\begin{array}{c}\text { Великі } \\
\text { підприємства }\end{array}$ & $\begin{array}{c}\text { Середні } \\
\text { підприємства }\end{array}$ \\
\hline 1 & 2 & 3 & 4 & 5 \\
\hline Трудові практики & 20 & 8,6 & 8,6 & 8,6 \\
\hline
\end{tabular}




\begin{tabular}{|c|c|c|c|c|}
\hline \multicolumn{5}{c|}{ Продовження табл. 11. } \\
\hline $\begin{array}{c}\text { Наявність кодексу } \\
\text { менеджменту }\end{array}$ & 2 & 3 & 4 & 5 \\
\hline $\begin{array}{c}\text { Наявність програми } \\
\text { соціального захисту }\end{array}$ & 4 & 0,1 & 0,1 & 0,1 \\
\hline $\begin{array}{c}\text { Наявність програми } \\
\text { сприяння розвитку }\end{array}$ & 4 & 2 & 2 & 2 \\
\hline $\begin{array}{c}\text { Відсоток } \\
\text { працівників, що } \\
\text { уклали колдоговір }\end{array}$ & 2 & 2 & 2 & 2 \\
\hline $\begin{array}{c}\text { Дотримання } \\
\text { гендерної рівності в } \\
\text { бізнесі }\end{array}$ & 3 & 2 & 2 & 0,5 \\
\hline $\begin{array}{c}\text { Забезпечення умов } \\
\text { праці (контроль } \\
\text { нещасних випадків, } \\
\text { оплати } \\
\text { понаднормового } \\
\text { навантаження) }\end{array}$ & 3 & 0,5 & 0,5 & 2 \\
\hline Разом & 100 & 2 & 2 & 19,1 \\
\hline
\end{tabular}

Навіть усвідомлення позитивних наслідків від впровадження КСВ практики не стимулює реальної повноти добровільного їх впровадження. Жодна 3 компаній не використовує професійність персоналу як конкурентну перевагу, підхід залишається ресурсно-витратним. $46,2 \%$ респондентів спеціальних опитувань надання соціальних гарантій персоналу забезпечить мало не кратне підвищення ефективності показників діяльності та конкурентоспроможності. Майже 32,5\% опитуваних наголошують на необхідності правової регламентації питань соціальної відповідальності.

\section{Висновки}

У результаті проведеного нами протягом 2009-2016 рр. опитування працівників 36 компаній харчової промисловості респонденти віднесли до складу характеристик суспільно відповідальної компанії такі чинники: випуск товарів високої якості (22\%), більш високу оплату праці (28\%), надання пакета соціального захисту працівникам і членам їх сімей $(23 \%)$, допомогу у вирішенні соціальних проблем (12\%), захист робочих місць (22\%), охорону навколишнього середовища $(10 \%)$, чітку сплату податків $(10 \%)$, надання підтримки бідним прошаркам населення та благодійність (9\%), захист національних інтересів (16\%). Дещо відрізняється підхід вищого менеджменту до проблеми суспільної відповідальності підприємства: $67 \%$ опитаних ранжували характеристики відповідальності у такому порядку: отримання прибутку, сплата податків, забезпечення робочими місцями, підтримка соціальних програм і суспільства в цілому, діяльність у рамках закону; 27\% менеджменту звузили підхід лише до трьох чинників: отримання прибутку, забезпечення робочими місцями, діяльність у рамках закону. Вказане змушує прийти до думки щодо існування перерозподільчих очікувань у сегменті 
працівників і формального - у сегменті вищого менеджменту. На наш погляд, це свідчить про збереження невизначеності у стратегіях розвитку підприємств, а також про затяжний період «аморального бізнесу» у національних ринкових відносинах, для виходу з якого годі чекати природного еволюціонування на грунті десятка прикладів, а скоріше треба використовувати методи державного управління та стимулювання процесу переходу до суспільно відповідальної конструкції корпоративного сектору.

\section{Література}

1. G-20.Офіційні матеріали : Додаток 3. Макети політики макроекономічної стабільності та соціальної відповідальності для всіх країн G-20 [Електронний ресурс]. — Режим доступу: http://ru.g20russia.ru/documents/\#p2.

2. Promulgation de la loi sur l'Economie Sociale et Solidaire : pour une croissance économique créatrice d'emplois non délocalisables [Електронний pecypc]. - Режим доступу: http://proxy-pubminefi.diffusion.finances.gouv.fr/pub/document/18/17847.pdf

3. Інститут стратегічних досліджень: Ukraine-analyisen. № 136 [Ел. журнал]. — Режим доступу: www.laender-analysen.de/ukraine;

4. Портер М. Конкурентоспособность и социальная ответственность / М. Портер, М. Креймер // Har. Bus. Rev. — Москва : ЗАО «Алмаз-Пресс», 2007. — № 3. — С. 73-86;

5. Обзор оплаты труда — PwC, Human recourses, 2013 [Электронный ресурс]. Режим доступа : http://www.pwc.com/en_UA/ua/press-room/2013/assets/paywell_012_13_ukraine_demoversion_rus_prot.pdf;

6. Ерхард $\bar{J}$. Социально-рыночное хазяйство / Л.Ерхард // Мировая экономическая мысль. Сквозь призму веков. В 5 Т. / Сопред.научно-ред. совета Г.Г. Фетисов, А.Г. Худокормов, Т.ІІІ. Эпоха социальных переломов / Отв. ред. А.Г. Худокормов. - Москва : Мысль, 2005. - 896 с.

7. Нова стратегія Європейської комісії з корпоративної соціальної відповідальності (КСВ) 2011—2014 [Електронний ресурс]. — Режим доступу : http://www.csr-ukraine.org/ ctrategiya_evropeyskoi_komisii_.html;

8. Діагностика стану та перспектив розвитку соціальної відповідальності в Україні (експертні оцінки): монографія / О.Ф. Новікова, М.С. Дейч, О.В. Панькова та ін.; НАН України, Ін-т економіки пром-сті. — Донецьк, 2013. — 296 с.

9. Исследование «Влияние кризиса на украинские компании» - Ернст и Янг, вх. № 219798 від 11.11.2008. - Апарат ВРУ.

10. Обзор оплаты труда - PwC, Human recourses, 2013 [Електронний ресурс]. Режим доступу : http://www.pwc.com/en_UA/ua/press-room/2013/assets/paywell_2012_13_ukraine_demoversion_rus_prot.pdf.

11. Інвестиційна привабливість регіонів // Опитування Київського міжнародного інституту соціології - Київ, 2013. — 337 с.

12. ALPRO [Електронний сайт]. — Режим доступу : http://www.alpro.com/ru/products/drinks/soya-plain.

13. Danone [Електронний сайт]. - Режим доступу : http://danone.ua/.

14. Enel [Електронний сайт]. - Режим доступу : http://enel.ru/. 